Article

\title{
Carbon Turnover during Effluent Application to the Land: A Potential Role for Vegetation?
}

\author{
Vasileios A. Tzanakakis ${ }^{1, *}$, Giannis Vagiakis ${ }^{2}$, Myrto Tsiknia ${ }^{2}$, Andreas N. Angelakis ${ }^{3}$ \\ and Nikolaos V. Paranychianakis ${ }^{2}$
}

1 Region of Crete, Directorate of Agricultural Economy, Iraklion 71201, Greece

2 School of Environmental Engineering, Technical University of Crete, Chania 73132, Greece; E-Mails: vagiakisgiannis@gmail.com (G.V.); myrtw_tsiknia@hotmail.com (M.T.); niko.paranychianakis@enveng.tuc.gr (N.V.P.)

3 National Agricultural Research Foundation (N.AG.RE.F.), Institute of Iraklion, Iraklion 71307, Greece; E-Mail: info@a-angelakis.gr

* Author to whom correspondence should be addressed; E-Mail: vetzanakakis@gmail.com; Tel.: $+30-2815002710$ or $+30-6977441455$.

Academic Editor: Shane Snyder

Received: 10 October 2014 / Accepted: 5 January 2015 / Published: 13 January 2015

\begin{abstract}
This work investigates the effect of plant species (Eucalyptus camaldulensis vs. Arundo donax) on carbon (C) turnover during wastewater application to the land. The study was carried out in 40-liter pots under field conditions and plant species were treated either with pre-treated municipal wastewater or freshwater. Plant species had a strong effect on soil organic matter with pots planted with E. camaldulensis showing greater values than pots planted with $A$. donax. In accordance, greater respiration rates were measured in E. camaldulensis pots compared to those planted with A. donax. The respiration rate followed a decreasing trend with the progress of the season for both species. These findings suggest differences in soil microbial community composition and/or activity in the rhizosphere of plant species. Minor effects of plant species or effluent were observed in dissolved organic carbon, protein, and hexoses content. In conclusion, the results of the present study reveal an important role of plant species on $\mathrm{C}$ cycling in terrestrial environments with potential implications on the sequestration of $\mathrm{C}$ and release of nutrients and pollutants.
\end{abstract}


Keywords: land application; land treatment; wastewater treatment; E. camaldulensis; A. donax; carbon cycling; respiration rate; carbon mineralization; dissolved organic carbon (DOC)

\section{Introduction}

Effluent application to the land constitutes a widespread practice and it contributes to the further treatment of effluents and the beneficial recycling of water and nutrients [1]. Depending on the pre-treatment level and composition, effluent application onto land may result in relatively high amounts of carbon (C). Previous studies have revealed the great potential of soil for $\mathrm{C}$ assimilation provided through effluent [2], but contrasting effects have been reported in the literature with the regard to its effect on soil organic matter (SOM) [2-4]. These findings indicate that environmental factors and management practices affect the turnover of the organic- $\mathrm{C}$ applied to the soil through effluent. Given the interest on the factors regulating $\mathrm{C}$ sequestration in soils and the release of nutrients, especially nitrogen $(\mathrm{N})$, concern for the fate of $\mathrm{C}$ in land treatment systems has been renewed. Thus, a better understanding of the processes regulating $\mathrm{C}$-cycling in effluent-irrigated lands is required to improve their potential for $\mathrm{C}$ and $\mathrm{N}$ assimilation and to reduce $\mathrm{N}$ losses to the environment.

Earlier studies dealing with effluent application showed enhancement of soil respiration rates, attributable to easily decomposable organic compounds in the effluent [5] which in turn stimulate microbial growth and activity [6,7]. However, such an influence is not always the case [8-10]. Many factors have been reported to affect the turnover of $\mathrm{C}$ in soils including the composition of organic substrate, soil properties and management, climatic conditions, and vegetation $[11,12]$. With regard to the effect of vegetation, its role has not been investigated in land treatment systems although indirect impacts have been proposed through its effect on effluent application rate and litter deposition [1]. Recent studies have provided evidence that plant species may affect the turnover of $\mathrm{C}$ in the soil through its effects on litter composition and rhizodeposition as well as microbial community composition and activity [5,13-15]. Given the high rates of effluent (and C) application, especially in areas with (semi)arid climates, it remains unclear whether the influence of plant species, if any, will be maintained or if it will be masked.

Up to date studies dealing with the role of vegetation in the treatment performance of land treatment systems have been mainly focused on its adaptation in salinity, biomass production, nutrient and heavy metal removal, water use, and soil (bio)chemical properties [1,2,16-18]. Thus, the purpose of this study is to investigate the influence of plant species (Eucalyptus camaldulensis and Arundo donax) on the turnover of $\mathrm{C}$ applied to the soil through effluent. To achieve this goal soil respiration rates, dissolved organic carbon (DOC) and SOM were monitored throughout the growing season. 


\section{Materials and Methods (or Experimental)}

\subsection{Site Description and Experimental Set Up}

The study was carried out in an experimental station close to Iraklion city ( $35^{\circ} 16^{\prime} 51^{\prime \prime} \mathrm{N}-25^{\circ} 10^{\prime} 53^{\prime \prime}$ E). The climate is semi-arid with relatively humid winters and dry and warm summers. In April 2010 one-year-old eucalyptus plants (E. camaldulensis) and rhizomes of giant reed (A. donax) were transplanted into separate pots $(40 \mathrm{~cm}$ in diameter $\times 40 \mathrm{~cm}$ in height), filled with surface soil taken form a fallow field. Pots were placed at $1.5 \mathrm{~m}$ distance within a row and at the same distance between rows. The chemical properties of the soil were $\mathrm{pH}: 7.59$, electrical conductivity (EC) $(\mathrm{dS} / \mathrm{m}): 0.35$, SOM (\%): 1.15, total kjeldahl nitrogen (TKN) (\%): 0.162, Olsen-P (mg/kg): 13.5, and $\mathrm{CaCO}_{3}(\%): 55 \%$.

Twelve replications per treatment (plant species) were used, while six additional pots planted with both species and irrigated with fresh water were also included to serve as controls. Pots were irrigated with primary treated wastewater transferred from the Wastewater Treatment Plant of Iraklion city. Effluent application started at the beginning of May and continued until the end of November. The average composition of the effluent, with regard to the parameters of interest, was chemical oxygen demand (COD): $617 \pm 120 \mathrm{mg} / \mathrm{L}$, biochemical oxygen demand (BOD 5 ): $247 \pm 45 \mathrm{mg} / \mathrm{L}, \mathrm{TKN}: 108 \pm 30 \mathrm{mg} / \mathrm{L}$, $\mathrm{NH}_{4}{ }^{+}-\mathrm{N}: 44 \pm 10 \mathrm{mg} / \mathrm{L}, \mathrm{NO}_{3}{ }^{-}-\mathrm{N}: 19 \pm 5 \mathrm{mg} / \mathrm{L}, \mathrm{EC}: 3.5 \pm 0.3 \mathrm{dS} / \mathrm{m}$, and $\mathrm{pH}: 7.5 \pm 0.2$. Plants were irrigated according to evapotranspiration demands determined by the use of tensiometers located at $20 \mathrm{~cm}$ depth. The frequency of irrigation varied from one irrigation per three days, early and late in the season (May to mid-June and October) to one irrigation per day or two days from July to September following climatic conditions and leaf area development. The cumulative hydraulic loading approached $2000 \mathrm{~mm}$. Hydraulic loading and reference evapotranspiration (ETo) are shown in Figure 1. No effect of plant species on water requirements was observed throughout the study period.

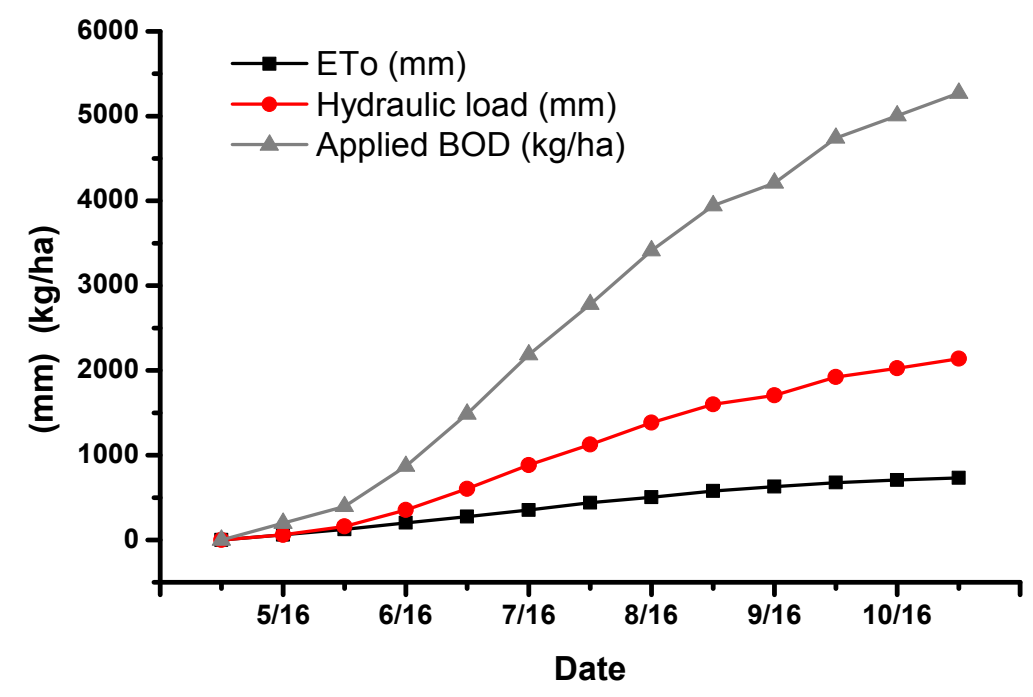

Figure 1. Cumulative reference evapotranspiration (ETo) and hydraulic and $\mathrm{BOD}_{5}$ loading of experimental pots throughout the study period. 


\subsection{Sampling and Chemical Analyses}

Representative soil samples of $200 \mathrm{~g}$ weight were collected from $0-13,13-26$, and $26-40 \mathrm{~cm}$ of soil profile by using a metallic soil sampler at fortnightly intervals during May and June and monthly during the rest period (July to October). The soil samples were prepared and analyzed according to the Soil Sampling and Methods of Analysis for SOM, DOC, exozes, and proteins [19]. Since no differentiation was found with soil depth the averaged values are presented.

\subsection{Respiration Rate}

The respiration rate assays were carried out under field conditions on 28 June, 25 August and 6 October. The respiration rates were estimated by capturing $\mathrm{CO}_{2}$ emissions from the soil within $24 \mathrm{~h}$. More detailed, after the uniform application of the irrigation dose at the pot surface, a PVC cylinder $(6.3 \mathrm{~cm}$ in diameter and $15 \mathrm{~cm}$ in height) with a gas-tight screw lid was immediately inserted at a depth of $3 \mathrm{~cm}$. To capture the generated $\mathrm{CO}_{2}$ a vial containing $10 \mathrm{~mL}$ of $1 \mathrm{M} \cdot \mathrm{NaOH}$ was placed inside the cylinder. The $\mathrm{NaOH}$ traps were replaced by new ones at 0.5 (only in the measurement of 25 August), $1,3,6$, and $24 \mathrm{~h}$ after irrigation (either with fresh water or wastewater). The concentration of $\mathrm{CO}_{2}$ was assessed by titration according to the Methods of Soil Analysis [20].

\subsection{Statistical Analysis}

Analysis of variance ANOVA was used for treatment comparison (plant species, irrigation water quality, and soil depth) on $\mathrm{CO}_{2}, \mathrm{SOM}, \mathrm{DOC}$, hexoses, and proteins. These statistical analyses were done using SPSS 19.0 software [21].

\section{Results}

\subsection{Organic Matter Loading}

The organic matter loading rate increased gradually until mid-June and then remained almost constant until the end of the application period (September), following the pattern of hydraulic loading rate. The cumulative organic matter loading $\left(\mathrm{kg} \cdot \mathrm{BOD}_{5} / \mathrm{ha}\right)$ applied in pots treated with effluent is shown in Figure 1.

\subsection{Soil Organic Matter Content, Dissolved Organic Matter, Hexoses, and Proteins}

Neither plant species nor effluent affected SOM content by 7 June. Then, SOM increased gradually in pots planted with E. camaldulensis until mid-July when it approached its maximum value (1.37\%). An opposite trend was identified in pots planted with A. donax in which SOM approached its minimum value (Figure 2a) at the same time. Thereafter and by the end of the study, SOM decreased gradually in pots planted with E. camaldulensis and approached its background levels (1.15\%). Surprisingly, SOM remained constant during the same period in pots planted with $A$. donax (Figure 2a). At the end of the study, SOM content differed significantly between plant species $(p<0.05)$. In pots irrigated with fresh water, no differences were observed in SOM content independently of the plant species (Figure 2a). 


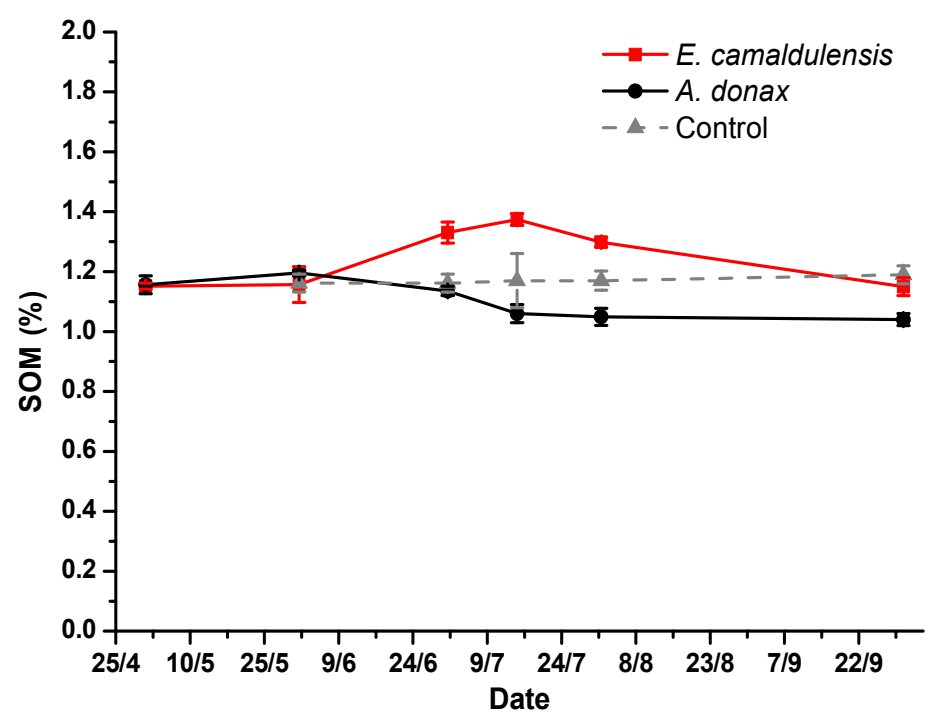

(a)
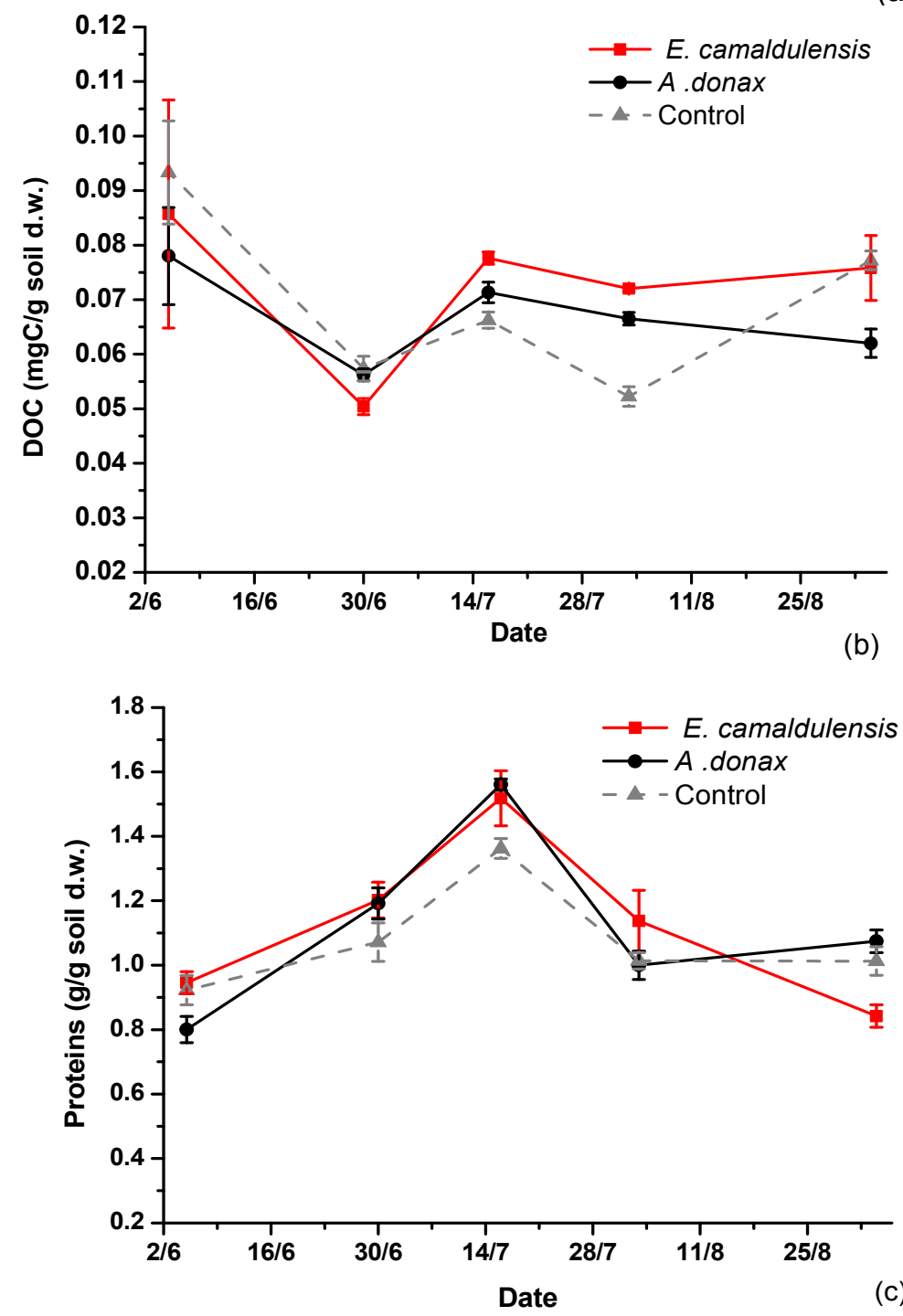

Figure 2. (a) Soil organic matter (SOM); (b) dissolved organic C (DOC); and (c) protein content in pots planted with E. camaldulensis and A. donax and irrigated with primary treated wastewater. Control refers to average of freshwater treated pots since no differences were observed between plant species. 
With regard to the DOC, a slight decrease was observed until the end of June independently of water source (Figure 2b). Thereafter, DOC increased by mid-July in effluent-irrigated pots, exceeding the concentration of DOC in pots irrigated with fresh water, and then remained constant (Figure 2b). In fresh water irrigated pots DOC remained constant until August, when a slight recovery took place (Figure 2b). A significant influence of plant species on DOC was observed from mid-July onwards, when pots planted with E. camaldulensis showed greater values of DOC compared to pots planted with A. donax (Figure 2b). At the study end (6 October) DOC content in E. camaldulensis pots was $22 \%$ higher compared to pots planted with $A$. donax $(p<0.05)$.

Protein concentration in soil solution samples increased in pots irrigated with fresh water until mid-July and then declined gradually to the concentrations measured at the beginning of the study (Figure 2c). A quite similar pattern was also observed for effluent-irrigated pots of A. donax. A differential response of protein concentration was found in effluent-irrigated pots of $E$. camaldulensis in which the concentration of proteins continued to decrease resulting finally in significant difference between plant species $(p<0.01)$ at the last sampling (Figure $2 \mathrm{c}$ ). Hexoses concentration showed fluctuations between samplings, but overall it was greater in the rhizosphere of E. camaldulensis (data not shown).

\subsection{Respiration Rates}

The respiration rate followed an exponential pattern including an initial rapid phase followed by a slower second one. It was significantly affected by both plant species and water source, while seasonal effects were also observed (Figure 3). In effluent-treated pots, at the first sampling when the greatest respiration rates were measured, E. camaldulensis showed $26 \%$ greater cumulative respiration compared to A. donax $(p<0.01)$ at $24 \mathrm{~h}$. Moreover, effluent-treated pots showed higher emissions of $\mathrm{CO}_{2}$ compared to pots irrigated with fresh water up to $32 \%$ for E. camaldulensis $(p<0.01)$ and $28 \%$ for A. donax $(p<0.01)$, respectively (Figure 3a).

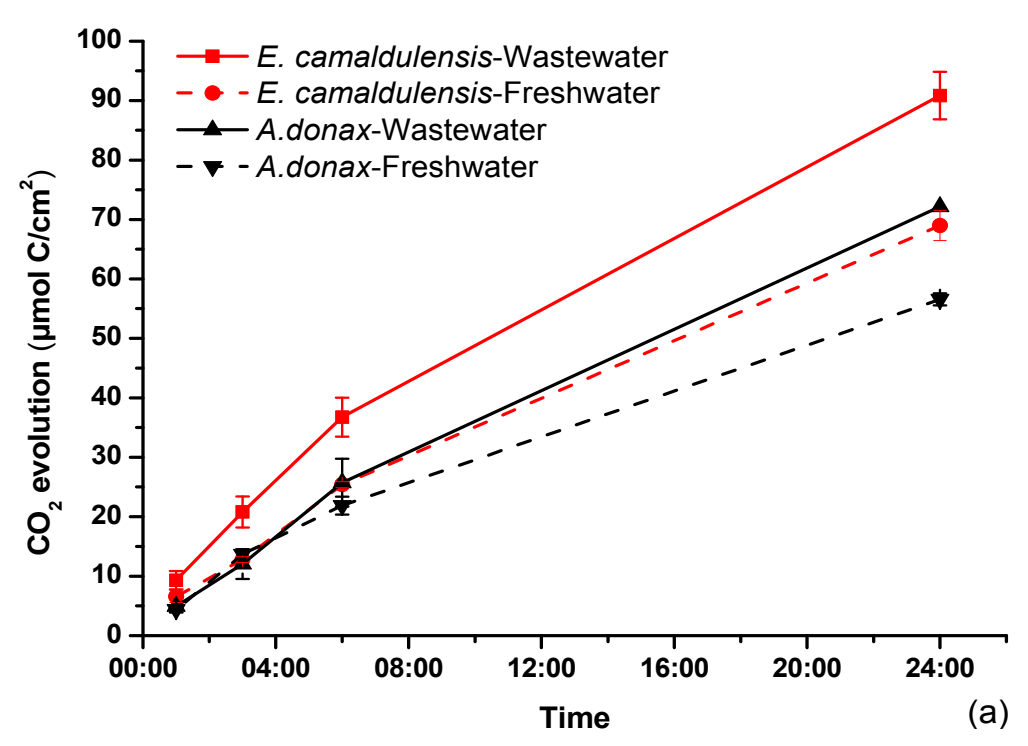

Figure 3. Cont. 

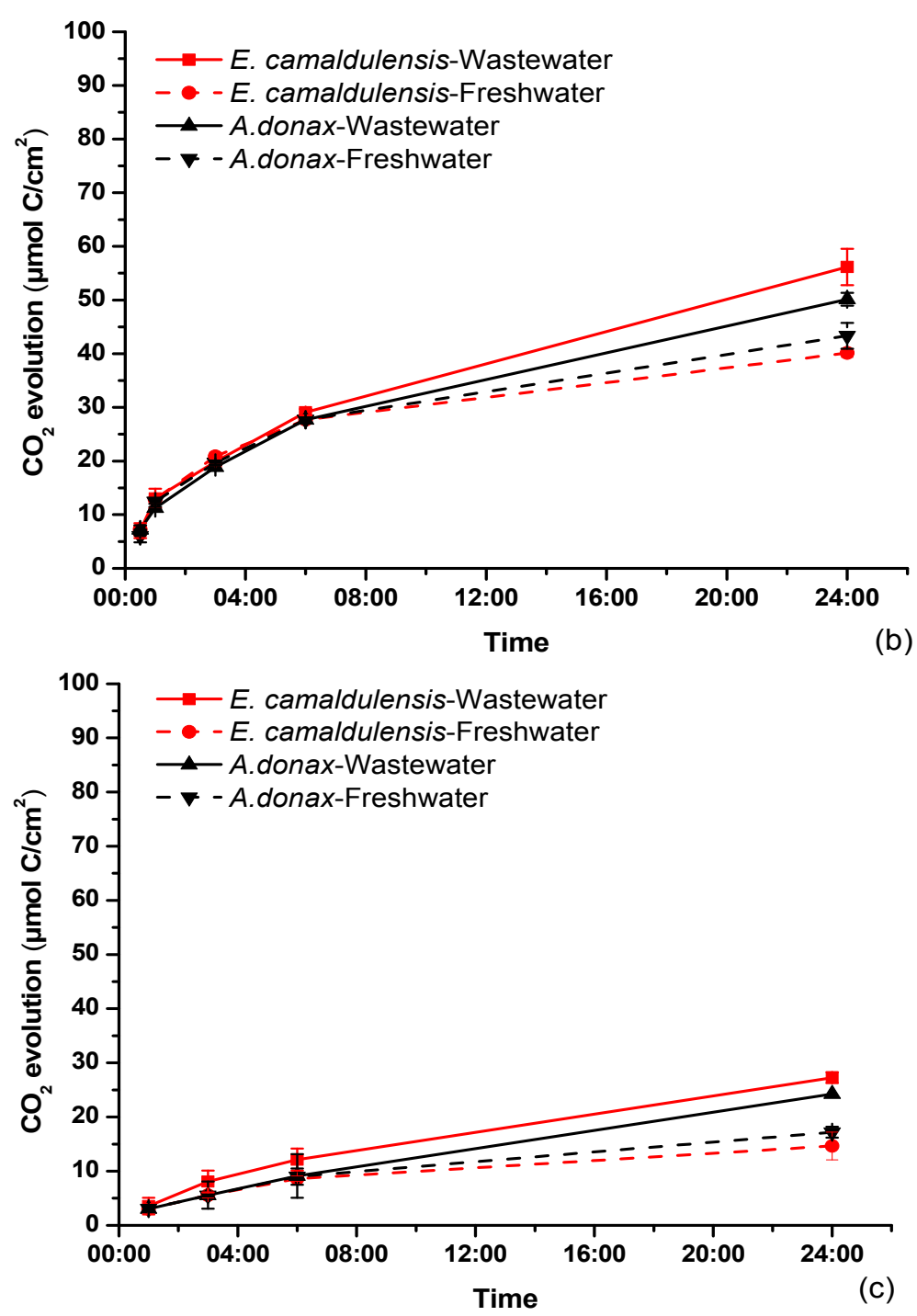

Figure 3. Emitted $\mathrm{CO}_{2}$ from pots planted with E. camaldulensis and A. donax plants and irrigated with primary treated wastewater and fresh water on (a) 28 June; (b) 25 August; and (c) 6 October.

These differences among effluent and fresh water irrigated plants became greater with the progress of the season approaching differences up to $86 \%$ and $41 \%$ for E. camaldulensis and A. donax, respectively at the last sampling (Figure 3b,c), suggesting that the contribution of the effluent-driven heterotrophic respiration to the overall $\mathrm{CO} 2$ evolution increased with progress of the season.

By subtracting the values of respiration of fresh water irrigated pots from those irrigated with effluent, to remove the autotrophic (root) and basal heterotrophic respiration [22], data supported again the seasonal pattern of decreasing $\mathrm{CO}_{2}$, despite the fact that organic $\mathrm{C}$ loading did not differ significantly among $\mathrm{CO}_{2}$ samplings (Figure 4). Moreover, this data revealed that the influence of plant species remained almost the same in absolute values over samplings. Considering this $\mathrm{CO}_{2}$ fraction, E. camaldulensis had $40 \%$ higher emissions of $\mathrm{CO}_{2}$ than $A$. donax at the first sampling, an effect that successively increased to $135 \%$ and $79 \%$ at the following samplings due to the greater contribution of respiration derived from the effluent. Finally, taking into account the applied $\mathrm{C}$ via effluent application and the net amount of $\mathrm{C}$ emission derived from effluent application, it was estimated that only $27 \%$ 
and $20 \%$ of the applied $\mathrm{C}$ was released at the first sampling at the eucalyptus and reed species, respectively (Figure 4).

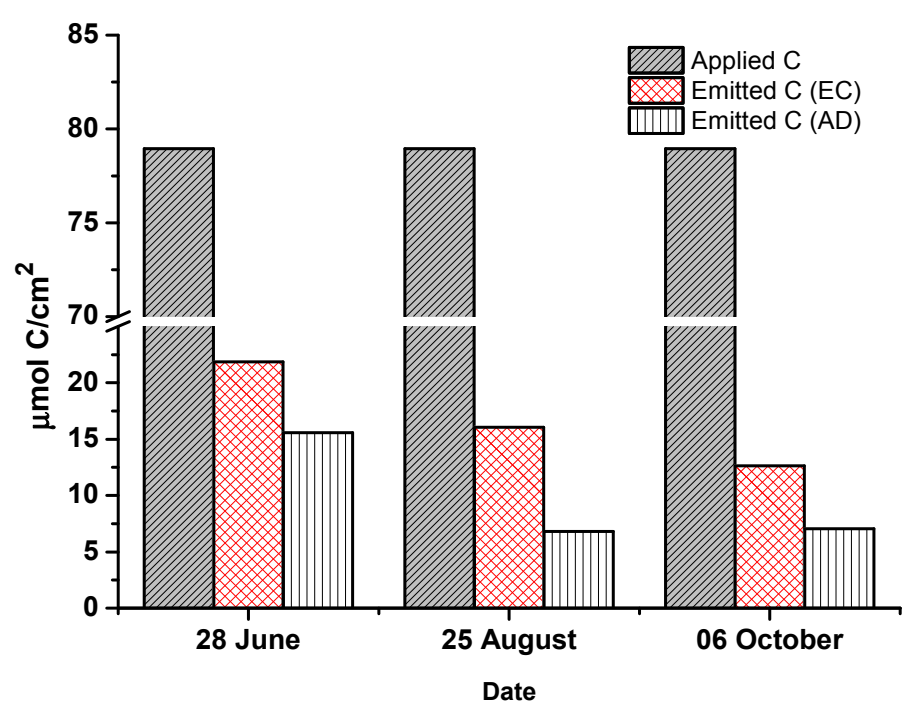

Figure 4. Estimated applied and net emitted C $24 \mathrm{~h}$ after effluent dose application at E. camaldulensis (EC) and A. donax (AD) pots.

\section{Discussion}

It is well documented that plant species can shape the soil microbial community and that this effect is largely driven by root activity and liter deposition rates and composition [23-25]. It remains however questionable if external application of organic substrates, e.g., effluent application, could modify this influence. Differences in microbial composition and enzyme activity were found in the rhizosphere of various plant species, and among them A. donax, in vertical flow constructed wetlands [26]. Accordingly, plant species influenced respiration, SOM and, to a lower extent, DOC and protein concentration in soil solution during the study period and this influence was only detected or exacerbated when effluent was used as a water source.

In agreement with earlier studies [27,28] effluent application stimulated $\mathrm{CO}_{2}$ emissions reflecting the enhancement of heterotrophic activity due to organic-C addition. Pots planted with E. camaldulensis showed constantly greater respiration rates than those planted with $A$. donax under effluent irrigation, but the mechanisms responsible remain to be elucidated. The greater concentrations of DOC in the rhizosphere of E. camaldulensis may suggest a greater release of root exudates that stimulated microbial activity, and thus $\mathrm{CO}_{2}$ emissions. The fact that the differences among plant species remained, even when the respiration from fresh water irrigated pots was subtracted to remove the effects of autotrophic respiration and rhizodeposition, documents a strong effect of plant species on the activity of microorganisms involved in organic- $\mathrm{C}$ mineralization. Moreover, this finding suggests that it is the availability of substrates that express the potential of vegetation to affect $\mathrm{C}$ cycling. This assumption explains the lack of differences among plant species in fresh water irrigated pots which can be attributed to the lower availability of substrates.

$\mathrm{CO}_{2}$ evolution across the treatments followed the characteristic biphasic pattern, including an initial rapid phase followed by a slower one [29,30]. It has been shown that a double exponential decay 
model describes better the mineralization of labile organic substrates added to the soil [29]. Application of a similar model was not possible in the present study since $\mathrm{CO}_{2}$ monitoring was limited to $24 \mathrm{~h}$. Another important limitation is that $\mathrm{CO}_{2}$ emission measured in effluent-irrigated pots is the cumulative effect of regularly repeated applications of effluent with variable contribution of various $\mathrm{C}$ pools. However, our data revealed that the only a portion of organic-C applied to the soil with the effluent was emitted as $\mathrm{CO}_{2}$ within this interval.

The normalized data of respiration (effluent respiration-fresh water respiration) suggests that the decline observed in $\mathrm{CO}_{2}$ emissions with the season's progress could only partially be explained by a decrease in autotrophic respiration and/or rhizodeposition as a consequence of plant ageing and the cessation of growth. These data also suggest that the SOM differences between plant species irrigated with effluent may have contributed (Figure 2a) to the occurrence of this pattern of respiration. Cumulative $\mathrm{CO}_{2}$ attributed to the effluent application from $A$. donax pots remained approximately the same in the last two samplings when SOM was constant, while in E. camaldulensis it continued to decline following the decrease in SOM (Figure 3b,c).

This study revealed a significant effect of plant species on SOM only in the effluent-irrigated pots. SOM declined rapidly early in the season in A. donax which may suggest a species-driven priming of SOM as has been shown in other studies [24,31]. The first measurement of $\mathrm{CO}_{2}$ coincided with the initiation of SOM decline attributed to the priming event, and the lower differences in respiration rate among plant species observed during that sampling (Figure 4) provide some documentation that SOM content had indeed an effect on respiration rate. Unlike $A$. donax, pots planted with $E$. camaldulensis showed a gradual accumulation in SOM during the first half of the study period. This finding clearly suggests a greater potential of the E. camaldulensis rhizosphere for temporary retention and/or stabilization of organic-C supplied through effluent application and rhizodeposition. Since the soil properties were the same, the mechanisms responsible for this effect remain obscure. Long term studies are required to fully address this issue and to provide further documentation for the effect of plant species on SOM.

Moreover, the findings of the present study revealed a seasonality of the influence of plant species on SOM (Figure 2) resulting probably from differences in exudation rates and the activity of the microbial community [32-34]. This hypothesis is supported by the observed decline in SOM differences among plant species towards the end of the growing season. Indeed plant species exerted a minor effect on microbial community in autumn attributed to low plant activity and high nutrient and energy inputs from litter fall [35].

\section{Conclusions}

In summary, plant species exerted a strong effect on the processes regulating the biogeochemical cycling of $\mathrm{C}$ in soils treated with effluent. Greater amounts of $\mathrm{CO}_{2}$ were emitted from the rhizosphere of E. camaldulensis compared to A. donax, an effect which is in agreement with the greater concentrations of DOC and hexoses measured. This effect of plant species remained even when the emissions of fresh water irrigated plants were subtracted from those irrigated with effluent to account for the contribution of autotrophic and basal soil respiration. A possible explanation is that E. camaldulensis stimulate changes in the activity and/or the composition of microorganisms involved 
in organic-C processing. Surprisingly, greater contents of SOM were also assessed in the rhizosphere of E. camaldulensis. These contrasting effects could only be explained by a priming effect on SOM induced by $A$. donax through yet unknown mechanisms. Apparently, further work is needed to elucidate the mechanisms through which vegetation affects SOM turnover as well as to test these effects in long-term trials.

\section{Acknowledgments}

Funding was provided by the Technical University of Crete.

\section{Author Contributions}

Myrto Tsiknia, Giannis Vagiakis and Vasileios A. Tzanakakis performed the experimental work and data collection; Vasileios A. Tzanakakis, Andreas N. Angelakis and Nikolaos V. Paranychianakis designed the experiment, performed statistical analysis, and prepared the manuscript.

\section{Conflicts of Interest}

The authors declare no conflict of interest.

\section{References}

1. Paranychianakis, N.; Angelakis, A.; Leverenz, H.; Tchobanoglous, G. Treatment of wastewater with slow rate systems: A review of treatment processes and plant functions. Crit. Rev. Environ. Sci. Technol. 2006, 36, 187-259.

2. Tzanakakis, V.A.; Paranychianakis, N.V.; Angelakis, A.N. Nutrient removal and biomass production in land treatment systems receiving domestic effluent. Ecol. Eng. 2009, 35, 1485-1492.

3. Tzanakakis, V.A.; Paranychianakis, N.V.; Londra, P.A.; Angelakis, A.N. Effluent application to the land: Changes in soil properties and treatment potential. Ecol. Eng. 2011, 37, 1757-1764.

4. Jueschke, E.; Marschner, B.; Tarchitzky, J.; Chen, Y. Effects of treated wastewater irrigation on the dissolved and soil organic carbon in Israeli soils. Water Sci. Technol. 2008, 57, 727-733.

5. Elifantz, H.; Kautsky, L.; Mor-Yosef, M.; Tarchitzky, J.; Bar-Tal, A.; Chen, Y.; Minz, D. Microbial activity and organic matter dynamics during 4 years of irrigation with treated wastewater. Microb. Ecol. 2011, 62, 973-981.

6. Cleveland, C.; Nemergut, D.; Schmidt, S.; Townsend, A. Increases in soil respiration following labile carbon additions linked to rapid shifts in soil microbial community composition. Biogeochemistry 2007, 82, 229-240.

7. Adrover, M.; Farrús, E.; Moyà, G.; Vadell, J. Chemical properties and biological activity in soils of Mallorca following twenty years of treated wastewater irrigation. J. Environ. Manag. 2012, 95, 188-192.

8. Zaman, M.; Cameron, K.C.; Di, H.J.; Inubushi, K. Changes in mineral N, microbial biomass and enzyme activities in different soil depths after surface applications of dairy shed effluent and chemical fertilizer. Nutr. Cycl. Agroecosyst. 2002, 63, 275-290. 
9. Ramirez-Fuentes, E.; Lucho-Constantino, C.; Escamilla-Silva, E.; Dendooven, L. Characteristics, and carbon and nitrogen dynamics in soil irrigated with wastewater for different lengths of time. Bioresour. Technol. 2002, 85, 179-187.

10. Truu, M.; Truu, J.; Heinsoo, K. Changes in soil microbial community under willow coppice: The effect of irrigation with secondary-treated municipal wastewater. Ecol. Eng. 2009, 35, 1011-1020.

11. Adrover, M.; Moyà, G.; Vadell, J. Effect of treated wastewater irrigation on plant growth and biological activity in three soil types. Commun. Soil Sci. Plant Anal. 2012, 43, 1163-1180.

12. Lõhmus, K.; Truu, M.; Truu, J.; Ostonen, I.; Kaar, E.; Vares, A.; Uri, V.; Alama, S.; Kanal, A. Functional diversity of culturable bacterial communities in the rhizosphere in relation to fine-root and soil parameters in alder stands on forest, abandoned agricultural, and oil-shale mining areas. Plant Soil 2006, 283, 1-10.

13. Cheng, W.; Kuzyakov, Y. Roots and Soil Management: Interactions between Roots and the Soiled. In Root Effects on Soil Organic Matter Decomposition, in Roots and Soil Management: Interactions between Roots and the Soil; Zobel, R.W., Wright, S.F., Eds.; American Society of Agronomy, Crop Science Society of America, Soil Science Society of America: Madison, WI, USA, 2005; pp. 119-143.

14. Nielsen, U.N.; Ayres, E.; Wall, D.H.; Bardgett, R.D. Soil biodiversity and carbon cycling: A review and synthesis of studies examining diversity-function relationships. Eur. J. Soil Sci. 2011, $62,105-116$.

15. Leff, J.; Nemergut, D.; Grandy, A.S.; O’Neill, S.; Wickings, K.; Townsend, A.; Cleveland, C. The effects of soil bacterial community structure on decomposition in a Tropical Rain Forest. Ecosystems 2012, 15, 284-298.

16. Strickland, M.S.; Lauber, C.; Fierer, N.; Bradford, M.A. Testing the functional significance of microbial community composition. Ecology 2009, 90, 441-451.

17. Tsiknia, M.; Tzanakakis, V.A.; Paranychianakis, N.V. Insights on the role of vegetation on nitrogen cycling in effluent irrigated lands. Appl. Soil Ecol. 2013, 64, 104-111.

18. Nsanganwimana, F.; Marchand, L.; Douay, F.; Mench, M. Arundo donax L., a candidate for phytomanaging water and soils contaminated by trace elements and producing plant-based feedstock. A review. Int. J. Phytoremed. 2013, 16, 982-1017.

19. Chantigny, M.; Angers, D.; Kaiser, K.; Kalbitz, K. Extraction and characterization of dissolved organic matter. In Soil Sampling and Methods of Analysis, 2nd ed.; Carter, M.R., Gregorich, E.G., Eds.; Taylor \& Francis Group, LLC: Boca Raton, FL, USA, 2007; pp. 617-635.

20. Weaver, R.W., Angle, S., Bottomley, P., Bezdicek, D., Smith, S., Tabatabai, A., Wollum, A., Mickelson, S. (Eds.) Methods of Soil Analysis: Part 2, Microbiological and Biochemical Properties; Soil Science Society of America: Madison, WI, USA, 1994.

21. IBM. IBM SPSS 19.0 for Windows; IBM Company: Armonk, NY, USA, 2010.

22. Hanson, P.J.; Edwards, N.T.; Garten, C.T.; Andrews, J.A. Separating root and soil microbial contributions to soil respiration: A review of methods and observations. Biogeochemistry 2000, 48, 115-146.

23. Berg, G.; Smalla, K. Plant species and soil type cooperatively shape the structure and function of microbial communities in the rhizosphere. FEMS Microbiol. Ecol. 2009, 68, 1-13. 
24. Haichar, F.E.Z.; Santaella, C.; Heulin, T.; Achouak, W. Root exudates mediated interactions belowground. Soil Biol. Biochem. 2014, 77, 69-80.

25. Shi, S.; Richardson, A.E.; O’Callaghan, M.; DeAngelis, K.M.; Jones, E.E.; Stewart, A.; Firestone, M.K.; Condron, L.M. Effects of selected root exudate components on soil bacterial communities. FEMS Microbiol. Ecol. 2011, 77, 600-610.

26. Ge, Y.; Zhang, C.; Jiang, Y.; Yue, C.; Jiang, Q.; Min, H.; Fan, H.; Zeng, Q.; Chang, J. Soil microbial abundances and enzyme activities in different rhizospheres in an integrated vertical flow constructed wetland. CLEAN Soil Air Water 2011, 39, 206-211.

27. Fernández-Luqueño, F.; Reyes-Varela, V.; Cervantes-Santiago, F.; Gómez-Juárez, C.; Santillán-Arias, A.; Dendooven, L. Emissions of carbon dioxide, methane and nitrous oxide from soil receiving urban wastewater for maize (Zea mays L.) cultivation. Plant Soil 2010, 331, 203-215.

28. Mapanda, F.; Mangwayana, E.N.; Nyamangara, J.; Giller, K.E. The effect of long-term irrigation using wastewater on heavy metal contents of soils under vegetables in Harare, Zimbabwe. Agric. Ecosyst. Environ. 2005, 107, 151-165.

29. Boddy, E.; Hill, P.W.; Farrar, J.; Jones, D.L. Fast turnover of low molecular weight components of the dissolved organic carbon pool of temperate grassland field soils. Soil Biol. Biochem. 2007, 39, 827-835.

30. Glanville, H.; Rousk, J.; Golyshin, P.; Jones, D.L. Mineralization of low molecular weight carbon substrates in soil solution under laboratory and field conditions. Soil Biol. Biochem. 2012, 48, 88-95.

31. De Graaff, M.-A.; Jastrow, J.D.; Gillette, S.; Johns, A.; Wullschleger, S.D. Differential priming of soil carbon driven by soil depth and root impacts on carbon availability. Soil Biol. Biochem. 2014, 69, 147-156.

32. Ucisik, A.S.; Trapp, S. Uptake, removal, accumulation, and phytotoxicity of phenol in willow trees (Salix viminalis). Environ. Toxicol. Chem. 2006, 25, 2455-2460.

33. Wang, X.; Piao, S.; Ciais, P.; Janssens, I.A.; Reichstein, M.; Peng, S.; Wang, T. Are ecological gradients in seasonal Q10 of soil respiration explained by climate or by vegetation seasonality? Soil Biol. Biochem. 2010, 42, 1728-1734.

34. Zhang, X.H.; Li, L.Q.; Pan, G.X. Topsoil organic carbon mineralization and CO2 evolution of three paddy soils from South China and the temperature dependence. J. Environ. Sci. China 2007, 19, 319-326.

35. Thoms, C.; Gleixner, G. Seasonal differences in tree species' influence on soil microbial communities. Soil Biol. Biochem. 2013, 66, 239-248.

(C) 2015 by the authors; licensee MDPI, Basel, Switzerland. This article is an open access article distributed under the terms and conditions of the Creative Commons Attribution license (http://creativecommons.org/licenses/by/4.0/). 